\title{
Pašaizsardzības pierādīšanas problēmas starptautiskajās publiskajās tiesībās
}

\author{
Mg. iur. Rihards Garais \\ Dr. iur. Jānis Grasis \\ Rīgas Stradiña universitāte, Juridiskā fakultāte, \\ Tiesību zinātṇu katedra, Latvija \\ Rihards.Garais@gmail.com \\ Janis.Grasis@rsu.lv
}

\section{Kopsavilkums}

Rakstā tiek apskatītas pierādīšanas problēmas starptautiskajās publiskajās tiesībās saistībā ar pašaizsardzību. Pierādījumu uzrādīšana Starptautiskajai tiesai noteikta ANO Starptautiskās tiesas Statūtu 48.-52. pantā. Nepastāv kāds metožu saraksts vai norādījumi uz pierādījuma vērtību. Formālas pierādījumu hierarhijas nav, tomēr Starptautiskā tiesa parasti dod priekšroku dokumentiem, nevis mutvārdu paziṇojumiem, tāpēc dokumentārie pierādījumi ir pirmā svarīgākā pierādīšanas metode.

Atslēgvārdi: pašaizsardzība, pierādījumi, ANO Starptautiskā tiesa.

\section{levads}

ANO Starptautiskā tiesa savulaik ir norādījusi, ka pašaizsardzības gadījumā valstij ir jāpierāda bruṇota uzbrukuma upura statuss un valstij, kas veic pašaizsardzības pasākumus, ir pierādī̌̌anas nasta [8].

Pētnieki norāda, ka piemērotākais standarts pašaizsardzības attaisnojumam ir skaidri un pārliecinoši pierādījumi. Tiesnesis sers Heršs Lauterpahts (Sir Hersch Lauterpacht) Norvēǵijas aizdevumu (Norwegian Loans) lietā norādīja, ka pierādījumu nastas līmenis nevar būt tik augsts, ka padara pierādījumu iesniegšanu par grūti izpildāmu prasību [5]. Savukārt skaidrs un pārliecinošs standarts valstij uzliek pienākumu rīkoties racionāli - tādā veidā, kas atbilst normālai valstu praksei identiskā vai līdzīgā situācijā, n,emot vērā, ka saprātīgas valstis nereagēe steigā, tās nepamatojas uz paviršām norādēm par agresorvalsti, kā arī pasīvi negaida, kamēr netiek savākti neapstrīdami pierādījumi [16]. 


\section{Pierādījumi ANO Starptautiskajā tiesā}

Pierādījumu uzrādīšana ANO Starptautiskajai tiesai ir noteikta šīs tiesas Statūtu 48.-52. pantā. Taču nepastāv kāds metožu saraksts vai norādījumi uz pierādījuma vērtību [14, 254]. Starptautiskās tiesas statūtu 48. pantā ir noteikts, ka "tiesai jāveic visi pasākumi, kas ir saistīti ar pierādījumu pieṇemšanu” [1], un tiesas procedūras noteikumu 58. pantā šis noteikums tiek apstiprināts: "darbībām ar pierādỉjumiem un jebkuru liecinieku vai ekspertu pratināšanai [..] jābūt noteiktai (settled) ar tiesu pēc pušu viedokḷu noskaidrošanas saskaṇā ar šo noteikumu 31. pantu” [2]. Šādu ierobežojošo noteikumu neesamību var izskaidrot kā tiesas ierosinājumu pusēm uzrādīt jebkurus pierādījumus kā tiesību jautājumu, ciktāl puses spēj to paveikt tiesas noteiktā laika robežās. Tātad pusēm pierādījumu uzrādīšanā tiek dota maksimāli liela rīcības brīvība [14, 255].

Pierādījumu uzrādīšana primāri ir pušu pienākums, tomēr arī Starptautiskā tiesa var organizēt pierādījumu vākšanu, lai pārbaudītu faktus. Saskaṇā ar statūtu 49. un 50. pantu faktu noskaidrošanas labad tiesa var noteikt dokumentu sagatavošanu, pieaicināt ekspertus un lieciniekus, apskatīt notikumu vietas un pieprasīt nozīmīgas ziṇas no starptautiskām organizācijām [1]. Kā piemērs ir tiesas atzinums Nikaragvas lietā, kuras izskatīšanā tā neaprobežojās tikai ar tām ziṇām un materiāliem, kurus iesniedza strīdā iesaistītās puses [7, 30. paragr.]. Gan šajā lietā, gan Kongo pret Ugandu lietā tiesa uzsvēra pierādījuma brīvas novērtēšanas principu (the principle of free assesment of evidence), norādot, ka tas ietverts ANO Starptautiskās tiesas Statūtos un noteikumos [4; 7, 60. paragr.]. Šajā aspektā spilgti parādās gan kontinentālās, gan arī anglosakšu tiesību sistēmas ietekme [18].

Dokumentārie pierādījumi ir pirmā svarīgākā pierādīšanas metode. Formālas pierādījumu hierarhijas nav, tomēr Starptautiskā tiesa parasti dod priekšroku dokumentiem, nevis mutvārdu paziṇojumiem [13, 232]. Dokumentārie pierādījumi ir "visu pušu iesniegtā informācija prāvas ietvaros savu apgalvojumu atbalstam, izṇemot ekspertu un liecinieku liecību" [19, 558].

Saskaṇā ar Šabtaja Rozenna (Shabtai Rosenne) viedokli dokumentāros pierādījumus var sadalīt četrās kategorijās:

- publicētie līgumi, kuri iekḷauti vienā no atzìtajiem - starptautiskajiem vai nacionālajiem - līgumu tekstu krājumiem;

- starptautisko organizāciju vai nacionālo parlamentu oficiālie dokumenti;

- publicētā un nepublicētā diplomātiskā korespondence, komunikē un dažādi citi materiāli, t. sk. grāmatas, kartes, plāni, shēmas, rēḳini, arhīvu materiāli, fotogrāfijas, filmas, tiesu un ekspertu atzinumi;

- rakstveida liecības un deklarācijas. [15, 1246]

Bosnijas genocīda lietas spriedumā tiesa norādīja uz šādiem dokumentārajiem pierādījumiem:

- dažādu ANO iestāžu ziņojumiem, rezolūcijām un konstatācijām;

- citu starpvalstu organizāciju dokumentiem, piemēram, Eiropas Drošības un sadarbības organizācijas; 
- bijušās Dienvidslāvijas Starptautiskās krimināltiesas dokumentiem (pierādījumiem un lēmumiem);

- valdību publikācijām;

- nevalstisko organizāciju dokumentiem;

- plašsaziṇas līdzekḷu ziṇojumiem, rakstiem un grāmatām. [3, 211. paragr.]

Oficiālie valsts dokumenti, piemēram, nacionālie normatīvie akti, doktrīnas, rokasgrāmatas, stratēgijas, direktīvas un militāra spēka izmantošanas noteikumi var kḷūt nozīmīgi valsts atbildības nodibināšanā arī paramilitāru aktivitāšu gadījumā [20]. Nikaragvas lietā ASV atbildība tika atzìta, pamatojoties uz psiholog̣isko operāciju rokasgrāmatu publikācijām [7, 30. paragr.]. Šìs lietas sprieduma 256. paragrāfā noteikts, ka šādu materiālu publikācija un izplatišsana tiek uzskatìta par iedrošinājumu veikt darbỉbas, kas ir pretrunā ar līgumos atspoguḷotajiem starptautisko humanitāro tiesību vispārējiem principiem. Šis atzinums nenozīmē, ka jebkurš valsts dokuments ir atzīstams par dokumentāro pierādījumu. Piemēram, Kongo pret Ugandu lietā Starptautiskā tiesa nepieņēma vairākus iekšējos militārās izlūkošanas dokumentus, jo tie nebija parakstīti, nebija autentificējami un informācija tajos nebija pilnvērtīgi paskaidrota [4, 127. paragr.].

Starptautiskās tiesas doktrīnā nepastāv noteikums par iespēju nesniegt informāciju, atsaucoties uz tās konfidencialitāti, kā tas notiek nacionālajos procesos. Daži pētnieki pat norāda, ka ir pienākums sniegt visus pierādïjumus, tostarp arī konfidenciālos. Tas izriet no pušu pienākuma rīkoties pēc labākas sirdsapziṇas [13, 49]. Lai gan pastāv šĩ diezgan stingrā prasība, tomēr nav paredzētas sankcijas par dokumentu nesniegšanu. Starptautiskās tiesas statūtu 49. pantā tikai noteikts, ka tiesai ir tiesības pieprasìt, lai tiktu uzrādīts jebkurš dokuments; gadijumā, ja puse atsakās to darīt, tiesa to piefiksē. Bijušās Dienvidslāvijas Starptautiskā krimināltiesa visai pamatoti norādīja, ka šāda carte blanche attiecībā uz pierādījumu nesniegšanu, to pamatojot ar konfidencialitātes ievērošanu, apgrūtina Starptautiskās tiesas pamatfunkcijas un tādējādi "apdraud tās būtisku priekšmetu un mērḳi" [9].

Starptautiskās tiesas praksē ir bijuši divi gadỉjumi, kad šis aspekts kḷuva par nopietnu problēmu, - Korfu kanāla lietā un Bosnijas genocīda lietā. Pirmajā gadījumā Apvienotā Karaliste un liecinieki atteicās uzrādìt dokumentus militāro jūras spēku noslēpumu dēḷ. Tiesas attieksme šajā jautājumā bija šāda: neuzsvērt Apvienotās Karalistes nostāju un nel̦aut šim faktam ietekmēt gala secinājumus [6, 32].

Bosnijas genocīda lietā Bosnija un Hercegovina vērsās tiesā, lai tā no Serbijas un Melnkalnes pieprasītu uzrādìt militārā noslēpuma dēl klasificētus dokumentus. Tiesa nolēma nepieprasìt šos dokumentus, atstājot sev tiesību pieprasìt tos pēc pašas iniciatīvas. Lai gan tiesa piebilda, ka pēc iesniedzēja norādes tā drīkst izdarīt secinājumus par Serbijas un Melnkalnes pierādījumu labprātīgas nesniegšanas faktu, tomēr nekas neliecina, ka šis fakts kaut kā ietekmēja tiesas nolēmumu [13, 214]. 
Arī starptautisko organizāciju dokumenti var tikt uzrādīti kā pierādỉjumi. Tiesu praksē priekšroka tiek dota ANO iestāžu dokumentiem. Bosnijas genocīda lietā tiesa norādīja, ka neatkarīgo vai oficiālo institūciju pierādỉjuma spēks ir atkarīgs no vairākiem aspektiem:

- pierādijjuma avota;

- pierādijjuma iegūšanas procesa;

- pierādijuma kvalitātes. [3, 227. paragr.]

Starptautiskā tiesa izmanto arī faktus konstatējošus komisiju un citu tiesu ziṇojumus [17, 152]. Piemēram, Portera komisijas ziṇojums tika izmantots Kongo pret Ugandu lietā, un, pamatojoties uz to, neviena no pusēm neapšaubija tā ticamību [4, 60]. Attiecībā uz šajā ziņojumā izmantoto pierādījumu iegūšanas procesu tiesa norādīja uz liecību savākšanas organizēto un kvalificēto raksturu. Starp savāktajiem pierādijjumiem bija arī tehniska rakstura informācija, kura, tiesas ieskatā, pelnīja īpašu uzmanību. [4, 61. paragr.]

Arī nevalstisko organizāciju un pētniecības centru dokumenti var kalpot par pierādījumiem, tomēr to loma ir ierobežota. Piemēram, raksturojot interneta vidi, NATO Kiberaizsardzības izcilības centrs Tallinā sagatavoja ziṇojumus par tehniskajām un juridiskajām diskusijām par informācijas pārraides incidentiem Igaunijā, Gruzijā, Irānā un citur [12].

Pastāv arī citu, piemēram, nevalstisko, organizāciju dokumenti, tomēr Starptautiskā tiesa uzskata tos par papildinošiem dokumentiem [13, 249]. Šāda pieeja tiek kritizēta, jo tiesas lietotie nevalstisko organizāciju dokumentu novērtēšanas kritēriji atšḳiras no pierādījumu novērtēšanas kritērijiem, kurus tiesa lieto pret ANO iestāžu pierādījumiem $[13,250]$.

Objektīvu iemeslu dēl arī plašsazinnas līdzekḷ ziṇas Starptautiskās tiesas avotu hierarhijā neatrodas augstā vietā, jo šì informācija parasti tiek pamatota ar vienu vai nedaudziem avotiem, informāciju sniedz ieinteresētā puse, nemaz nerunājot par gadījumiem, kad avoti nav identificējami [4, 68. paragr.]. Nikaragvas lietā tiesa atzina preses materiālu un grāmatu fragmentu augsto kvalitāti, tomēr tie tika uzskatīti par sekundāriem avotiem, kuri izmantojami tikai kopsakarā ar pamata pierādījumiem [7, 62. paragr.].

Starptautiskās tiesas procesā liela nozīme ir oficiālajiem paziṇojumiem, kā tas tika norādīts Teherānas ḳilnieku lietā, kurā tiesa konstatēja milzīgu skaitu gan ASV, gan Irānas varas iestāžu paziņojumu par šā procesa priekšmetu [10]. Nikaragvas lietā par īpaši nozīmīgiem tiesa atzina tos valsts paziņojumus, kuros augstākā ranga politiḳi atzina, ka viṇu pārstāvētās valsts darbības ir pelnījušas kritiku [7, 64. paragr.]. Protams, tiesa pievērsa uzmanību arī tam, kur šìs ziṇas tika publicētas, jo oficiālam paziṇojumam ir lielāks pierādī̌̌anas spēks nekā publikācijai laikrakstā vai grāmatā.

Tiesa vai kāda no pusēm var pieaicināt lieciniekus mutvārdu liecību sniegšanai. To nosaka divi apstāklıi:

- procesa otrai pusei nav iebildumu;

- tiesa atzīst, ka liecībai var būt nozīme procesa gaitā [2, 62. panta otrā daḷa, 63. pants]. 
Saskaṇā ar Starptautiskās tiesas Statūtu 50. pantu tiesa var jebkurā laikā piesaistīt jebkuru personu, institūciju, biroju, komisiju vai citu organizāciju, kas veiks izmeklēšanu vai paudīs eksperta viedokli [1]. Eksperti ir nepieciešami situācijās, kuru izvērtēšanai vajadzīgas augsta līmeņa tehniskās vai citas specifiskas zināšanas. Dažkārt pieaicināšanai ir citi iemesli, piemēram, Korfu kanāla lietā tiesa piesaistija ekspertu grupu, lai izvērtētu pušu nepārvaramos pretrunīgos uzskatus par konkrētiem faktiem [6, 4, 9]. Arī pašas puses var piesaistìt ekspertus, kuri, sniedzot mutvārdu atzinumus, dod zvērestu par savu kompetenci un profesionālajām spējām [14, 263].

Austrālija un Japāna - iesaistītās puses lietā par valı medībām Antarktikā - kā pierādījumus uzrādīja ekspertu atzinumus. Šie eksperti tika nopratināti, un viṇu atzinumus tiesa diezgan plaši izmantoja arī savā spriedumā. [11]

Viens no galvenajiem pierādījumu piel̦aujamības jautājumiem ir šāds: vai ir vērā ņemami prettiesiski iegūtie pierādijumi? Starptautiskās tiesas Statūtos nav noteikumu par pierādījumu nepiel̦aujamību, pat gadỉjumā, ja tie iegūti ar darbībām, kas starptautiski tiek uzskatītas par prettiesiskām [13, 158]. Piemēram, Korfu kanāla lietā tiesa pieṇēma pierādijumus, kurus prettiesiski ieguva Apvienotā Karaliste operācijā "Mazumtirdzniecība" (Operation "Retail"), un, pamatojoties tieši uz šiem pierādijumiem, tiesa noteica incidenta notikšanas vietu un mīnu veidu $[6,14,15]$. Albānija šo pierādijjumu piel̦aujamību nekad neapstrīdēja, un tiesa neizskatīja piel̦aujamības jautājumu [14, 271].

Pētnieki norāda, ka tiesa ar savu pieeju - neradot tiešu aizliegumu - mēginana panākt, lai valstis atsakās no prettiesiskas pierādijjuma uzrādišanas; tā padara prettiesisku pierādījumu vākšanu par nevajadzīgu, jo atbilstīgos apstākḷos tiesa gatava pien̦emt arī sekundāros pierādījumus [14, 271, 272]. Turpretī, kā norāda pētnieki, ja, iegūstot pierādījumus, notiek ius cogens pārkāpšana, šāda pierādījumu sagādāšana nav nepiel̦aujama $[19,563]$.

\section{Secinājumi}

Izskatot pierādīšanas problēmas, var secināt, ka ir izveidojusies pietiekami plaša Starptautiskās tiesas prakse par pierādīšanas metodēm, kuras ir izmantojamas arī strīdos par spēka lietošanas tiesiskumu, tostarp arī par pašaizsardzības pamatojumu. Jān̨em vērā arī tas, ka pierādīšanai Starptautiskās tiesas praksē daudz uzmanības tiek pievērsts valsts attieksmei saistībā ar konfliktu, gan raugoties no politiskajiem apstākḷiem, gan arī no tiesību normām, tiek ņemts vērā ne vien militārpersonu viedoklis, bet arī politisko lēmumu pieñēmēju un pat tiesību pētnieku viedoklis. 


\section{Problems of Proof of Self-defence in International Public Law}

\section{Abstract}

The article aims to the problems of proof in international public law relating to self-defence. The submission of evidences to the International Court is governed by Articles 48 to 52 of the Charter of the International Court of Justice of the United Nations. There is no list of methods or indications of the value of the proof. Despite the absence of a formal hierarchy of evidences, the International Court of Justice generally prefers documents rather than verbal statements, so documentary evidence is the first most important method of proof.

Keywords: self-defence, proof, the International Court of Justice of the United Nations.

\section{Avoti un literatūra}

\section{Tiesību akti}

1. Apvienoto Nāciju Organizācijas Starptautiskās tiesas Statūti: starptautisks dokuments, parakstīts 26.06.1945. Latvijas Vēstnesis. 20(6106), 29.01.2018.

2. United Nations: Rules of Court. I. C. J. Basic documents. Iegūts no: https://www.icj-cij.org/en/ rules [sk. 20.04.2019.].

\section{Tiesu prakse}

3. Application of the Convention on the Prevention and Punishment of the Crime of Genocide (Bosnia \& Herzegovina v. Serbia \& Montenegro): Judgment of 26th February 2007. I. C. J. Reports. 2007, 43. Iegūts no: https://www.icj-cij.org/files/case-related/91/091-20070226-JUD-01-00-EN. pdf [sk. 07.04.2019.].

4. Armed Activities on the Territory of the Congo (Democratic Republic Congo v. Uganda): Judgment of 19th December 2005. I. C. J. Reports. 2005, 168. Iegūts no: https://www.icj-cij.org/ files/case-related/116/116-20051219-JUD-01-00-EN.pdf [sk. 07.04.2019.].

5. Certain Norwegian Loans (France v. Norway): Judgment of 6th July 1957: Separate Opinion of Judge sir Hersch Lauterpacht. I. C. J. Reports. 1957, 9. Iegūts no: https://www.icj-cij.org/files/ case-related/29/029-19570706-JUD-01-03-EN.pdf) [sk. 07.04.2019.].

6. Corfu Channel (U. K. v. Alb.): Judgment of 9th April 1949. I. C. J. Reports. 1949. Iegūts no: https:// www.icj-cij.org/files/case-related/1/001-19490409-JUD-01-00-EN.pdf [sk. 07.04.2019.].

7. Military and Paramilitary Activities in and Against Nicaragua (Nicar. v. U. S.): Judgment of 27th June 1986. I. C. J. Reports. 1986. Iegūts no: https://www.icj-cij.org/files/case-related/70/07019860627-JUD-01-00-EN.pdf [sk. 07.04.2019.].

8. Oil platforms (Islamic Republic of Iran v. United States of America): Judgment of 6th November 2003. I. C. J. Reports. 2003. Iegūts no: https://www.icj-cij.org/files/case-related/90/090-20031106JUD-01-00-EN.pdf [sk. 15.04.2019.]. 
Rihards Garais, Jānis Grasis. Pašaizsardzības pierādīšanas problēmas starptautiskajās publiskajās tiesībās

9. Prosecutor v. Blaškić, Case No. IT-95-14-AR: Judgment on the Request of the Republic of Croatia for Review of the Decision of Trial Chamber II of 18th July 1997: Judgment of 29th October 1997. United Nations International Criminal Tribunal for the Former Yugoslavia. 1997, par. 65. Iegūts no: http://www.icty.org/x/cases/blaskic/acdec/en/71029JT3.html [sk. 20.04.2019.].

10. United States Diplomatic and Consular Staff in Tehran (U. S. v. Iran), Judgment of 24th May 1980. I. C. J. Reports. 1980, par. 13. Iegūts no: https://www.icj-cij.org/files/case-related/64/06419800524-JUD-01-00-EN.pdf [sk. 14.04.2019.].

11. Whaling in the Antarctic (Aust. v. Japan: N. Z. intervening), Judgment of 31st of March 2014 I. C. J. Reports. 2014, par. 227. Iegūts no: https://www.icj-cij.org/files/case-related/148/14820140331-JUD-01-00-EN.pdf [sk. 14.04.2019.].

\section{Literatūra}

12. NATO Opens New Centre of Excellence on Cyber Defence. 2008. NATO. Iegūts no: http://www. nato.int/docu/update/2008/05-may/e0514a.html [sk. 20.01.2019.].

13. Riddell, A., Plant, B. 2009. Evidence Before the International Court of Justice. London: British Institute of International and Comparative Law.

14. Roscini, M. 2015. Evidentiary Issues in International Disputes Related to State Responsibility for Cyber Operations. Texas International Law Journal. 50, Symposium Issue 2.

15. Rosenne, S. 2006. The Law and Practice of the International Court, 1920-2005. Vol. III, Procedure. Leiden, Boston: Martinus Nijhoff Publishers.

16. Schmitt, M. N. 2011. Cyber Operations and the Jus Ad Bellum Revisited. Villanova Law Review. $56,569,595$.

17. Teitelbaum, R. 2007. Recent Fact-Finding Developments at the International Court of Justice. In: 6th Law and Practice of International Courts and Tribunals.

18. Tomka, P., Proulx, V.-J. 2015. The Evidentiary practice of the World Court. National University of Singapore, Faculty of Law Working Paper Series.

19. Wolfrum, R. 2012. International Courts and Tribunals, Evidence: 5th Encyclopedia of Public International Law. Amsterdam, New York, Oxford: North-Holland Publishing Company.

20. Young, M. D. 2010. National Cyber Doctrine: The Missing Link in the Application of American Cyber Power. Journal of National Security Law E Policy. Iegūts no: http://jnslp.com/wp-content/ uploads/2010/08/12_Young.pdf [sk. 22.01.2019.]. 